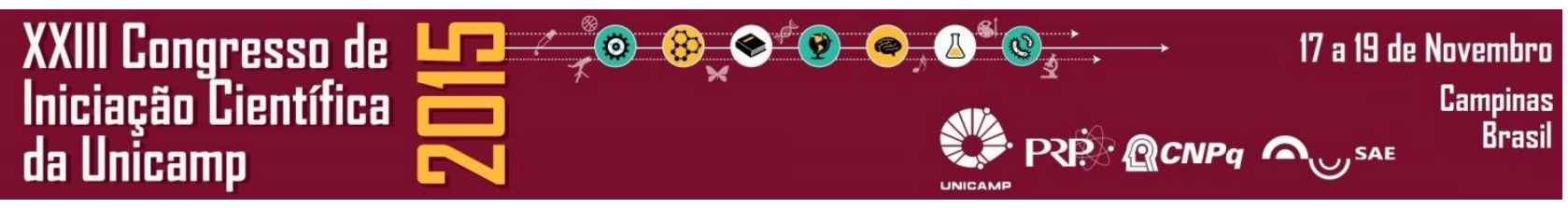

\title{
Similarities and Differences between two Libraries in the Nineteenth Century - A Comparison between the Novels of the Imperial Library and the Fluminense Library.
}

\section{Larissa de Assumpção (IC)}

\section{Abstract}

The aim of this work, that is a part of the thematic project "The Transatlantic Circulation of Printed Matter: the Globalization of the Culture in the $19^{\text {th }}$ Century", is to compare the catalogues of a public and a private library of the nineteenth century. The comparison between the Imperial Library, formed by the Imperial Family of Brazil, and the Fluminense Library, a public library of Rio de Janeiro in the $19^{\text {th }}$ century, can reveal some similarities and some differences between the novels that were read by the Brazilian elite and by the general public. The comparison between the most prominent authors in each library and the main languages of the books can also contribute to the understanding of the presence of novels in Rio de Janeiro in the nineteenth century.

Key words: Libraries, novels, nineteenth century.

\section{Introduction}

The Fluminense Library was a public library of Rio de Janeiro. Its catalogue, published in 1866, contains more than 1200 novels.

The Imperial Library was formed by the Imperial Family during the $19^{\text {th }}$ Century. It contains more than 680 novels, of which 446 were published until 1866.

The similarities and differences between the collections can help to understand the formation of both libraries and the preferences of their readers.

\section{Results and Discussion}

One of the differences between the libraries is the main languages in each one, as can be seen in the image below:

Image 1. The percentage of the main languages in each Library

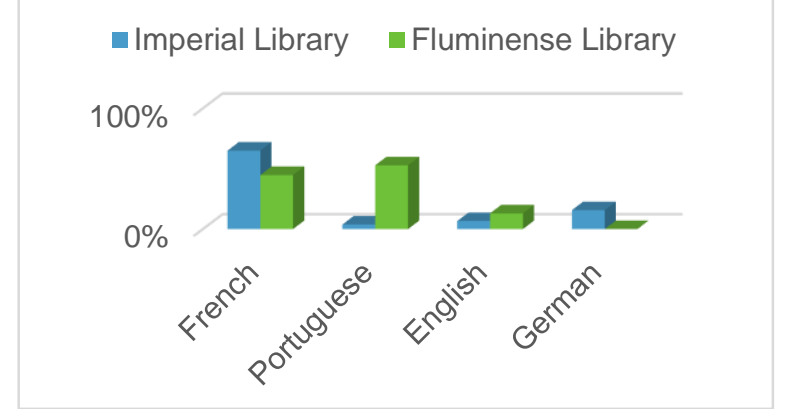

The main authors in each collection are not the same, as we can see in the image below:

\begin{tabular}{|c|c|c|}
\hline $\begin{array}{l}\text { Name of the } \\
\text { Author }\end{array}$ & $\begin{array}{l}\text { Number of Novels } \\
\text { in the Imperial } \\
\text { Library }\end{array}$ & $\begin{array}{l}\text { Number of Novels } \\
\text { in the Fluminense } \\
\text { Library }\end{array}$ \\
\hline $\begin{array}{l}\text { Carl Franz van der } \\
\text { Velde }\end{array}$ & 24 (all in German) & $\begin{array}{l}2 \text { (both in } \\
\text { Portuguese) }\end{array}$ \\
\hline Alexandre Dumas & 1 (in Portuguese) & $\begin{array}{l}80 \text { (38 in } \\
\text { Portuguese and } 42 \\
\text { in French) }\end{array}$ \\
\hline Paul de Kock & 0 & $\begin{array}{l}61 \text { ( } 29 \text { in } \\
\text { Portuguese and } 32 \\
\text { in French) }\end{array}$ \\
\hline Maria Edgewoth & $\begin{array}{l}7 \text { ( } 4 \text { in French and } 3 \\
\text { in English) }\end{array}$ & 2 (both in French) \\
\hline
\end{tabular}

\section{Conclusions}

There are important differences between the library of the Imperial Family of Brazil and the Fluminense Library, such as the languages in which the books were read and the main authors.

These differences also indicate that the elite had a different taste in comparison with the general public, even when it deals with novel, a popular and discredited genre in the $19^{\text {th }}$ century.

\section{Acknowledgement}

Adviser: Profa. Dra. Márcia Abreu This project is funded by FAPESP (São Paulo Research Foundation)

ABREU, Márcia (Org.). Trajetórias do Romance: Circulação, leitura e escrita nos séculos XVIII e XIX. Campinas: Mercado de Letras, 2008. 